\title{
UPAYA MENINGKATKAN AKTIVITAS SISWA DAN PEMAHAMAN KONSEP PERUBAHAN ZAT MELALUI PROBEX
}

\author{
Jaryanto. \\ SMP Negeri 1 Pringapus
}

\begin{abstract}
ABSTRAK
Pembelajaran secara konvensional materi perubahan zat belum menghasilkan prestasi belajar maksimal, karena itu diperlukan inovasi pembelajaran dengan Predict-Observe-Explain (Probex). Tujuan penelitian ini adalah meningkatkan aktivitas dan pemahaman siswa terhadap konsep Perubahan Zat melalaui (Probex). Penelitian ini dilakukan pada siswa kelas VII B SMP Negeri 1 Pringapus tahun pelajaran 2013/2014. Penelitian dilaksanakan dalam tiga siklus, setiap siklus terdiri empat tahap, yaitu perencanaan, tindakan, observasi, dan refleksi. Teknik pengumpulan data dilakukan dengan observasi, dokumentasi, wawancara, dan tes. Analisa secara kuantitatif dan kualitatif. Hasil penelitian menunjukkan bahwa peningkatan penilaian sikap ilmiah kategori baik (3\%), keterampilan proses kategori baik (5\%), keaktifan mengerjakan LKS 15\%, prestasi belajar 13\%. Simpulan penelitian ini adalah pembelajaran melalui Probex dapat meningkatkan aktivitas pemahaman konsep materi Perubahan Zat. Disarankan untuk diadakan penelitian lanjutan pembelajaran dengan Probex untuk meningkatkan motivasi dan minat siswa.
\end{abstract}

Kata Kunci : Metode Probex, Pembelajaran IPA, Konsep Perubahan Zat

\section{PENDAHULUAN}

Proses pembelajaran IPA adalah proses yang kompleks dan saling berhubungan antara materi satu dengan yang lainnya. Konsep awal yang diterima siswa menjadi syarat untuk penguasaan konsep berikutnya. Pengetahuan awal siswa pada setiap pengalaman belajarnya akan berpengaruh terhadap bagaimana mereka kan belajar dan apa yang akan mereka pelajari selanjutnya (Haryanto, 2000: 24). Guru harus bisa mengintegrasikan faktor kondisi sosial, tujuan pengembangan berpikir, teori-teori belajar, dan teknologi sehingga diperoleh hasil pembelajaran sebaik mungkin, artinya bahwa metode pembelajaran yang diterapkan oleh guru dapat memberikan peluang kepada siswa mengembangkan kemampuan intelektualnya untuk memahami konsep-konsep IPA (Depdikbud, 1996).

Namun demikian, kenyataan menunjukkan bahwa 8 dari 38 siswa kelas VII B SMP Negeri 1 Pringapus tahun pelajaran 2013/2014 nilai ulangan harian di bawah KKM. Hal ini disebabkan antara lain (1) metode pembelajaran konvensional (ceramah), (2) siswa malas belajar, (3) aktivitas siswa rendah/pasif, (4) motivasi dan minat siswa rendah. Dengan demikian guru harus mencari solusi pemecahannya. Salah satunya dengan variasi metode pembelajaran. Metode pembelajaran yang baik 
akan menghasilkan prestasi belajar yang memuaskan dan sebaliknya metode pembelajaran yag kurang tepat akan membuat siswa kurang termotivasi dan dampak selanjutnya bagi siswa adalah menurunnya prestasi belajar. Salah satu alternatif metode yang dapat diterapkan dalam proses belajar mengajar IPA adalah metode pembelajaran Probex (Predict-Observe-Explain) Metode pembelajaran Probex didasarkan atas teori pembelajaran konstruktivisme yang memberi kesempatan siswa untuk menyadari apa yang telah menjadi pengetahuan awal mereka. Mereka berinteraksi dengan alat bahan, membuat prediksi (predict), menguji prediksi melalui pengamatan (observe), dan kemudian mengemukakan penjelasan mengenai fenomena yang mereka hadapi (explain). Setelah itu, mereka menguji dan menyempurnakan penjelasan itu, atau bahkan memodifikasinya (Haryanto, 2000: 24).

Ada beberapa alasan, mengapa peneliti memandang perlu dilaksanakannya penelitian tindakan kelas ini, yaitu: (1) Metode pembelajaran Probex merupakan metode yang baru dalam pembelajaran, sehingga perlu dikaji keefektifannya; (2) Mata Pelajaran IPA, khususnya Konsep Perubahan Zat sangat dekat dengan kehidupan sehari-hari siswa, sehingga metode pembelajaran Probex sesuai untuk diterapkan dalam pembelajaran; (3) Ketuntasan hasil belajar siswa kelas VII SMP Negeri 1 Pringapus secara klasikal pada mata pelajaran IPA untuk konsep Perubahan Zat masih kurang dari 75\%; dan (4) Metode pembelajaran Probex dapat membantu siswa membentuk ide baru berdasarkan pengetahuan dan pengalaman yang telah dimiliki sebelumnya, dan (5) Metode pembelajaran yang digunakan dalam pembelajaran IPA untuk konsep Perubahan Zat selama ini masih menggunakan metode konvensional

Metode pembelajaran Probex memungkinkan siswa untuk memformulasikan pengetahuan baru dan pengalaman yang telah mereka miliki sebelumnya. Strategi ini juga memberikan kesempatan kepada siswa untuk memikirkan kembali dan mengubah miskonsepsi mereka terhadap suatu masalah. Probex menantang siswa untuk berpikir dan memberikan kepuasan tertentu apabila prediksi siswa ternyata sesuai dengan hasil pengamatan (Rustanto, 2001: 3).

Berdasarkan uraian tersebut, maka muncul permasalahan apakah pembelajaran Probex dapat meningkatkan pemahaman konsep Perubahan Zat pada siswa kelas VII B SMP Negeri 1 Pringapus tahun pelajaran pelajaran 2013/2014. Tujuan penelitian tindakan kelas ini adalah (1) meningkatkan pemahaman siswa terhadap konsep Perubahan Zat pada mata pelajaran IPA yang diajarkan menggunakan metode Probex, (2) Meningkatkan aktivitas belajar siswa dalam pembelajaran IPA. Sedangkan kerangka berpikir pembelajaran probex terlihat pada Gambar 1. 


\begin{tabular}{|c|c|c|}
\hline Keadaan Sekarang & Alternatif Tindakan & Hasil yang diharapkan \\
\hline$\downarrow$ & $\downarrow$ & $\downarrow$ \\
\hline $\begin{array}{l}\text { 1. } \begin{array}{l}\text { Pembelajaran } \\
\text { IPA kurang } \\
\text { bervariasi, masih } \\
\text { konvensional } \\
\text { (ceramah). }\end{array} \\
\text { 2. } \begin{array}{l}\text { Siswa sulit } \\
\text { memahami konsep }\end{array} \\
\text { Perubahan Zat. } \\
\text { 3. Siswa belajar } \\
\text { secara individual. } \\
\text { 4. } \begin{array}{l}\text { Siswa kurang aktif } \\
\text { dalam }\end{array} \\
\text { pembelajaran. } \\
\text { Ketuntasan hasil } \\
\text { belajar secara } \\
\text { klasikal kurang } \\
\text { dari } 75 \% \text {. }\end{array}$ & $\begin{array}{l}\text { 1. } \begin{array}{l}\text { Menambah variasi } \\
\text { metode }\end{array} \\
\text { pembelajaran. } \\
\text { 2. Menerapkan metode } \\
\text { pembelajaran Probex } \\
\text { (Predict-Observe- } \\
\text { Explain). } \\
\text { 3. Mengembangkan } \\
\text { daya nalar dan } \\
\text { kreatifitas siswa. } \\
\text { 4. Mengaktifkan siswa } \\
\text { dalam pembelajaran. }\end{array}$ & $\begin{array}{l}\text { Kualitas proses } \\
\text { pembelajaran IPA untuk } \\
\text { konsep Perubahan Zat } \\
\text { meningkat, dengan } \\
\text { ditunjukkan oleh } \\
\text { keaktifan dan } \\
\text { peningkatan hasil } \\
\text { belajar siswa. }\end{array}$ \\
\hline$\downarrow$ & $\downarrow$ & $\downarrow$ \\
\hline Evaluasi Awal & Evaluasi Proses & Evaluasi Akhir \\
\hline
\end{tabular}

Gambar 1. Kerangka Berpikir Pembelajaran Probex

\section{METODE PENELITIAN}

Penelitian ini dilaksanakan pada siswa kelas VII B SMPN 1 Pringapus kecamatan Pringapus kabupaten Semarang tahun pembelajaran 2013/2014, dengan jumlah 38 siswa, yang terdiri dari 15 siswa laki-laki dan 23 siswa perempuan. Variabel yang diteliti meliputi pemahaman konsep perubahan zat, aktivitas (sikap ilmiah, ketrerampilan proses dan respon siswa). Alat pengumpul data yang diperlukan berupa lembar observasi, pedoman wawancara, tes. Lembar observasi hasil wawancara digunakan untuk triangulasi data, menganalisis aktivitas siswa sedangan tes digunakan untuk menganalisis pemahaman konsep perubahan zat. Penelitian ini dirancang menjadi tiga siklus dan tiap-tiap siklus terdiri atas perencanaan, tindakan, observasi dan refleksi. Rancangan penelitian keseluruhan dapat dilihat pada Gambar. 3.

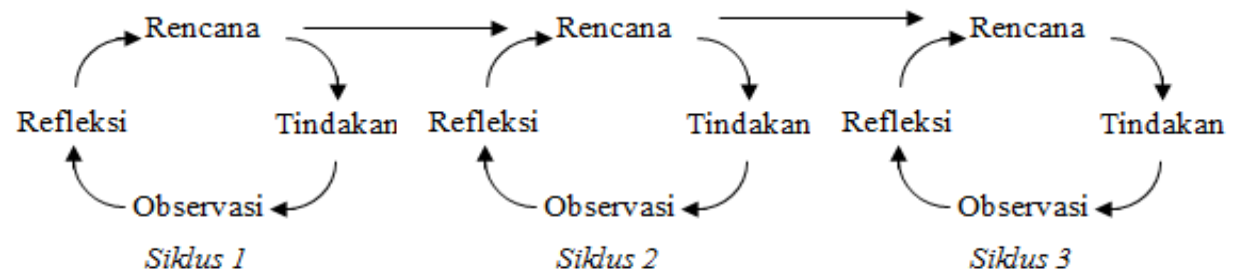

(Kasihani Kasbolah E.S, $1999 ; 36)$

Gambar 3. Siklus Rancangan Penelitian

\section{Indikator Keberhasilan}

Indikator keberhasilan dalam penelitian ini adalah (1) jika 85\% dari jumlah seluruh siswa tuntas KKM pada materi Perubahan Zat; (2) aktivitas siswa telah mencapai kategori baik. 


\begin{tabular}{|c|c|c|}
\hline No & Interval & Kategori \\
\hline 1 & $85-100$ & Sangat Baik (SB) \\
\hline 2 & $70-84$ & Baik (B) \\
\hline 3 & $55-69$ & Cukup (C) \\
\hline 4 & $40-54$ & Kurang (K) \\
\hline 5 & $00-39$ & Sangat Kurang (SK) \\
\hline
\end{tabular}

(Arikunto : 1990)

\section{HASIL PENELITIAN DAN PEMBAHASAN}

\section{Hasil Penelitian}

\section{Sikap Ilmiah}

Aspek-aspek yang diamati dalam penilaian sikap ilmiah siswa adalah: (1) Sikap ingin tahu; (2) Sikap mendapatkan sesuatu yang baru; (3) Sikap kerjasama; (4) Sikap tidak putus asa; (5) Sikap tidak berprasangka; (6) Sikap mawas diri; (7) Sikap bertanggung jawab; (8) Sikap berpikir bebas; dan (9) Sikap disiplin diri. Hasil penelitian dari sikap ilmiah ditunjukkan Tabel 1.

Tabel 1 Rerata Sikap Ilmiah

\begin{tabular}{clcccc}
\hline No & \multicolumn{1}{c}{ Aspek yang Diamati } & Siklus I & Siklus II & Siklus III & Rerata \\
\hline 1 & Sikap ingin tahu & 80 & 82 & 83 & 81.67 \\
2 & Sikap mendapatkan sesuatu yang & 79 & 80 & 82 & 80.33 \\
& baru & 78 & 79 & 82 & 79.67 \\
3 & Sikap kerjasama & 79 & 82 & 82 & 81.00 \\
4 & Sikap tidak putus asa & 80 & 80 & 82 & 80.67 \\
5 & Sikap tidak berprasangka & 78 & 80 & 82 & 80.00 \\
6 & Sikap mawas diri & 79 & 79 & 82 & 80.00 \\
7 & Sikap bertanggung jawab & 78 & 80 & 80 & 79.33 \\
8 & Sikap berpikir bebas & 80 & 80 & 82 & 80.67 \\
9 & Sikap kedisiplinan diri & 78.88 & 80.00 & 81.75 & 80.21 \\
& $\quad$ Rerata & & $2,5 \%$ & & \\
\hline
\end{tabular}

Berdasarkan Tabel 1 tersebut, dapat dijelaskan bahwa terjadi peningkatan sikap ilmiah siswa dalam pembelajaran. Rerata hasil pengamatan pada siklus I hanya sebesar 78,88. Pada siklus II rerata hasil pengamatan meningkat menjadi 80,00, sedangkan di siklus III, peningkatan rerata hasil pengamatan menjadi sebesar 81,75. Rerata keseluruhan hasil pengamatan observer terhadap sikap ilmiah siswa adalah sebesar 80,21, sehingga dapat dikategorikan baik.

\section{Keterampilan Proses Siswa}


Aspek-aspek yang diamati dalam penilaian keterampilan proses siswa adalah: (1) Keterampilan mengamati; (2) Keterampilan mengklasifikasi; (3) Keterampilan menafsirkan; (4) Keterampilan memprediksi; (5) Keterampilan membuat hipotesis; (6) Keterampilan melakukan eksperimen; (7) Keterampilan mengkomunikasikan; dan (8) Keterampilan mengaplikasikan. Hasil dari penilaian keterampilan proses siswa dapat dilihat pada Tabel 2.

Tabel 2. Rekap Keterampilan Proses Siswa

\begin{tabular}{|c|c|c|c|c|c|}
\hline No & Aspek yang Diamati & Siklus I & Siklus II & Siklus III & Rerata \\
\hline 1 & Keterampilan mengamati & 80 & 82 & 83 & 81.67 \\
\hline 2 & Keterampilan mengklasifikasi & 78 & 82 & 84 & 81.33 \\
\hline 3 & Keterampilan menafsirkan & 76 & 78 & 80 & 78.00 \\
\hline 4 & Keterampilan memprediksi & 79 & 80 & 82 & 80.33 \\
\hline 5 & Keterampilan membuat hipotesa & 80 & 82 & 82 & 81.33 \\
\hline 6 & $\begin{array}{l}\text { Keterampilan melaksanakan } \\
\text { eksperimen }\end{array}$ & 78 & 84 & 85 & 82.33 \\
\hline 7 & $\begin{array}{l}\text { Keterampilan } \\
\text { mengkomunikasikan }\end{array}$ & 76 & 80 & 81 & 79.00 \\
\hline \multirow[t]{3}{*}{8} & Keterampilan mengaplikasikan & 75 & 76 & 78 & 76.33 \\
\hline & Rerata & 77.75 & 80.50 & 81.88 & 80.04 \\
\hline & Kenaikan Total & & $5,3 \%$ & & \\
\hline
\end{tabular}

Tabel 2 tersebut menjelaskan bahwa terjadi peningkatan keterampilan proses siswa. Siklus I, rerata hasil pengamatan hanya sebesar 77,75. Pada siklus II rerata hasil pengamatan meningkat menjadi 80,50, sedangkan di siklus III, peningkatan rerata hasil pengamatan menjadi sebesar 81,88. Rerata keseluruhan hasil pengamatan observer terhadap keterampilan proses siswa adalah sebesar 80,04 , sehingga dapat dikategorikan baik.

\section{Lembar Kerja Siswa}

Lembar kerja siswa yang dibuat dilengkapi dengan tujuan, pengantar materi, alat dan bahan, cara kerja, kolom prediksi, kolom observasi, dan kolom penjelasan. Lembar kerja didesain sesuai langkahlangkah metode Probex agar siswa lebih mudah mempelajari konsep yang diajarkan Penilaian dilakukan terhadap masing-masing kelompok yang seluruhnya berjumlah 6 (enam) kelompok. Hasil dari penilaian lembar kerja siswa dapat dilihat pada Tabel 3. 
Tabel 3. Rekap Hasil Lembar Kerja Siswa

\begin{tabular}{ccccc}
\hline No & Kelompok & Siklus I & Siklus II & Siklus III \\
\hline 1. & Kelompok 1 & 70 & 75 & 80 \\
2. & Kelompok 2 & 70 & 80 & 85 \\
3. & Kelompok 3 & 75 & 80 & 85 \\
4. & Kelompok 4 & 80 & 80 & 80 \\
5. & Kelompok 5 & 70 & 75 & 90 \\
6. & Kelompok 6 & 75 & 80 & 85 \\
& Jumlah & 440 & 470 & 505 \\
& Rerata (\%) & 73 & 78 & 84 \\
& Kenaikan & & $15 \%$ & \\
\hline
\end{tabular}

Berdasarkan Tabel 3 tersebut, dapat diketahui bahwa terjadi peningkatan kemampuan siswa dalam mengerjakan LKS di tiap siklus. Siklus I, rerata pengerjaan LKS hanya sebesar 73,33. Pada siklus II rerata hasil pengerjaan LKS meningkat menjadi 78,33, sedangkan di siklus III, peningkatan rerata pengerjaan LKS menjadi sebesar 84,17.

\section{Prestasi Belajar}

Peneliti mengadakan evaluasi sebagai bentuk penialain produk dengan tujuan untuk mengukur kemampuan siswa dalam memahami konsep Perubahan Zat yang telah diajarkan melalui metode Probex. Evaluasi dilaksanakan pada akhir pembelajaran di tiap siklus, sehingga terdapat tiga kali evaluasi dalam penelitian ini. Sebagai pembanding, digunakan hasil belajar siswa sebelum pembelajaran dengan metode Probex. Rerata hasil belajar IPA siswa setelah menggunakan metode Probex dapat dilihat pada Tabel 4 berikut.

Tabel 4. Rekap Prestasi Belajar

\begin{tabular}{llcc}
\hline No & Pelaksanaan & Rerata Nilai & $\begin{array}{c}\text { Prosentase } \\
\text { Ketercapaian (\%) }\end{array}$ \\
\hline 1 & Awal & 58.82 & 0 \\
2. & Siklus I & 64.44 & 78 \\
3. & Siklus II & 68.42 & 86 \\
4. & Siklus III & 71.58 & 92 \\
& Kenaikan Total & 12.76 & 21 \\
\hline
\end{tabular}

Berdasarkan Tabel 4 tersebut, maka dapat dibandingkan prestasi belajar IPA konsep Perubahan Zat sebelum menggunakan metode Probex $(56,82)$ dan sesudah menggunakan metode Probex (12.76). Setelah menggunakan metode Probex, pada siklus I hasil belajar siswa meningkat menjadi 64.44, siklus II meningkat menjadi 68.41, dan di siklus III meningkat lagi menjadi 71.58. 
Secara garis besar, hasil penelitian yang telah dilakukan pada setiap pertemuan di siklus I, II, dan III memiliki beberapa kekuatan dan juga kelemahan. Kelebihan Probex adalah (1) Siswa lebih semangat belajar dan sangat merespon penjelasan guru, ditunjukkan dengan keaktifan siswa dalam memprediksi, melakukan percobaan, memberikan penjelasan, mengemukakan pendapat, dan melakukan tanya jawab dengan guru, (2) Suasana kelas menjadi lebih kondusif dan tertib setelah dilakukan pembelajaran IPA dengan metode Probex, (3) Guru lebih mudah memonitor kegiatan pembelajaran secara individu maupun kelompok, (4) Pembelajaran IPA dengan metode Probex cukup efektif untuk meningkatkan pemahaman siswa terhadap konsep Perubahan Zat. Sedangkan kelemahan Probex adalah (1) Siswa yang memiliki kemampuan lamban dan semangat belajar kurang, tampak lebih aktif saat dilaksanakan pembelajaran IPA dengan metode Probex, tetapi hasil belajar yang diperoleh masih kurang maksimal, (2) Pengawasan guru terhadap siswa yang sedang belajar masih belum optimal, karena jumlah siswa yang cukup banyak.

\section{Pembahasan}

Pembelajaran IPA adalah proses yang kompleks dan saling berhubungan antara materi satu dengan yang lainnya. Konsep awal yang diterima siswa menjadi syarat untuk penguasaan konsep berikutnya. Pembelajaran IPA yang dilakukan selama ini masih sekedar memberikan konsep-konsep sains, tanpa menggali pengetahuan awal siswa. Metode konvensional juga masih mendominasi dalam pembelajaran IPA. Guru selalu berperan sebagai sumber informasi utama, dan siswa sebagai sekelompok pendengar, tidak ada variasi pembelajaran bahkan pembelajaran cenderung monoton.

Peneliti mencoba menerapkan strategi pembelajaran yang cukup menarik dalam pembelajaran IPA di SMP, yaitu metode Probex (Predict-Observe-Explain). Metode pembelajaran Probex yang diterapkan dalam penelitian ini, memungkinkan siswa untuk memformulasikan pengetahuan baru dan pengalaman yang telah dimiliki sebelumnya. Metode Probex juga memberikan kesempatan siswa untuk memikirkan kembali dan mengubah miskonsepsi mereka terhadap suatu fenomena.

Setelah guru menerapkan metode Probex dalam pembelajaran IPA, maka keaktifan siswa mulai tampak. Keaktifan siswa tersebut ditunjukkan dari beberapa kegiatan pada saat pembelajaran, antara lain antusias siswa dalam memberikan prediksi, melakukan eksperimen, melakukan diskusi, memberikan penjelasan, melakukan tanya jawab, dan berpendapat .

Pembelajaran dilakukan dalam tiga kali pertemuan (3 x 40 menit) atau melalui tiga siklus. Pada siklus I, guru melaksanakan pembelajaran IPA konsep perubahan zat untuk sub konsep perubahan fisika dan perubahan kimia menggunakan metode Probex. Tujuan dari pembelajaran ini adalah agar siswa dapat mengidentifikasi perubahan fisika dan perubahan kimia melalui percobaan sederhana. Siklus II, guru melakukan pembelajaran IPA konsep perubahan zat untuk sub konsep ciri-ciri reaksi kimia menggunakan 
metode Probex. Tujuan dari pembelajaran pada siklus ini adalah agar siswa mengetahui ciri-ciri reaksi kimia dengan melaksanakan percobaan sederhana. Sedangkan di siklus III, difokuskan pada pembelajaran IPA konsep perubahan zat sub konsep faktor-faktor yang mempengaruhi kecepatan reaksi kimia. Tujuan pembelajaran di siklus ini adalah melalui percobaan sederhana, siswa dapat menjelaskan faktor-faktor yang mempengaruhi kecepatan reaksi kimia.

Berdasarkan data hasil penelitian, maka dapat disimpulkan telah terjadi peningkatan rerata hasil belajar IPA konsep Perubahan Zat pada siswa kelas VII B SMP Negeri 1 Pringapus (dari 56,82, sebelum diberi tindakan menjadi 68,25, setelah siswa diberi pembelajaran IPA dengan metode Probex). Hal tersebut menunjukkan bahwa metode Probex cukup efektif untuk meningkatkan pemahaman siswa terhadap konsep IPA yang diajarkan.

Sesuai dengan hasil observasi yang telah dilakukan, maka dapat diketahui bahwa pembelajaran di siklus I masih perlu beberapa perbaikan. Hal tersebut peneliti sadari karena metode Probex adalah baru untuk siswa, sehingga harus diadaptasikan dan guru sepenuhnya membimbing siswa dalam pembelajaran. Pembelajaran di siklus II dan siklus III sudah cukup baik, karena siswa aktif dalam pembelajaran dan guru tidak sepenuhnya memberikan bimbingan.

Pada setiap siklus, guru selalu mencoba mengajak siswa untuk memprediksikan perubahan yang terjadi jika disajikan suatu fenomena yang berbeda-beda, sesuai dengan ciri pembelajaran Probex. Hal ini bertujuan untuk mengetahui kemampuan awal dan pengetahuan yang diperoleh siswa sebelumnya. Guru juga mengajak siswa menciptakan pola pikir dalam memadukan konsep awal siswa dan tujuan pembelajaran melalui pemberian kesempatan untuk membandingkan hasil prediksi dengan hasil percobaan yang telah dilakukan. Siswa diminta memberikan penjelasan mengapa terjadi perbedaan hasil prediksinya dengan hasil percobaan. Tujuan dari kegiatan ini adalah untuk memantapkan konsep awal siswa jika sudah sesuai dengan teori dan mengubah miskonsepsi siswa yang selama ini dianggap benar. Berdasarkan hasil prediksi siswa dalam LKS, dapat diketahui bahwa kemampuan siswa dalam memprediksi baik, dibuktikan dengan cukup banyaknya prediksi siswa yang sesuai dengan hasil percobaan di setiap siklus. Proses tanya jawab dan diskusi sebagai variasi pembelajaran ikut mendukung terciptanya keefektifan belajar, karena memudahkan guru dalam menerapkan langkah-langkah metode Probex.

Sikap ilmiah yang menunjukkan nilai tertinggi $(81,67)$ adalah pada sikap ingin tahu. Hal tersebut dikarenakan adanya keingtahuan siswa yang besar untuk mengikuti pembelajaran IPA dengan metode Probex. Sedangkan sikap berpikir bebas dalam penilaian sikap ilmiah memiliki nilai terendah $(79,33)$. 
Hal ini dimungkinkan karena siswa belum terbiasa berpikir bebas dalam pembelajaran IPA, apalagi dengan metode atau pendekatan yang baru.

Penilaian keterampilan proses siswa, nilai tertinggi adalah pada keterampilan melaksanakan eksperimen (82,33). Hal ini disebabkan dalam eksperimen, hanya menekankan pada kemampuan panca indera. Sedangkan jenis keterampilan proses terendah adalah pada keterampilan mengaplikasi $(76,33)$. Hal tersebut dikarenakan bahwa hasil pembelajaran yang telah dilakukan belum dapat secara langsung diaplikasikan dalam kehidupan siswa. Sejalan dengan pendapat Rustanto (2001) yang mengatakan bahwa siswa untuk berpikir dan memberikan kepuasan dalam taraf tertentu apabila prediksi siswa sesuai dengan hasil yang diharapkan.

Sebelum menggunakan metode Probex dalam pembelajaran IPA, rerata nilai hasil belajar siswa hanya sebesar 56,82. Setelah guru menerapkan metode Probex dalam pembelajaran IPA, nilai belajar siswa menjadi meningkat. Hal tersebut dibuktikan pada siklus I, rerata nilai belajar siswa sebesar 64,74, siklus II sebesar 68,42, dan siklus III sebesar 71,58. Terjadinya peningkatan rerata nilai ini dapat dijelaskan karena sebelum menerapkan metode Probex, guru lebih dominan menggunakan metode klasikal, yaitu ceramah atau tanya jawab saja. Ternyata, pembelajaran yang monoton tersebut menyebabkan respon siswa menjadi rendah dan keaktifan siswa dalam pembelajaran belum tampak. Setelah menerapkan metode Probex dalam pembelajaran IPA, keaktifan siswa terlihat. Dengan melibatkan siswa secara langsung dalam pembelajaran, misalnya pada saat percobaan dan diskusi, keberanian siswa untuk mengerjakan maupun bertanya tumbuh.

Hasil wawancara dengan siswa setelah penerapan metode Probex dapat disimpulkan bahwa mereka menyenangi pembelajaran IPA dengan metode tersebut. Wawancara dilakukan secara spontan kepada seluruh siswa, setelah selesai evaluasi pada siklus III. Semua siswa mengacungkan jari saat guru menanyakan: "Siapa yang senang pelajaran IPA seperti yang telah kita lakukan tadi?" Mereka mengharapkan guru untuk dapat menerapkannya. Semua siswa menjawab ya, ketika guru menanyakan: “Apakah kalian suka, jika melakukan pembelajaran seperti tadi pada lain waktu?"

Sedangkan hasil wawancara dengan observer dilakukan di ruang guru, setelah metode Probex selesai diterapkan kepada siswa. Dari hasil wawancara, peneliti memperoleh beberapa informasi yang sangat berarti bagi peneliti sehubungan dengan penelitian yang telah dilakukan. Saat peneliti bertanya, apakah metode Probex efektif untuk pembelajaran IPA, observer berpendapat bahwa metode ini cukup efektif dan efisien. Observer I beralasan bahwa pendekatan ini efektif karena lebih banyak mengaktifkan siswa. Sedangkan observer II berpendapat bahwa pendekatan ini mampu mengintegrasikan konsep dan penanaman sikap ilmiah siswa. Pertanyaan selanjutnya kepada observer adalah apakah metode Probex 
perlu dikembangkan pada kajian lain, observer menjawab perlu, namun dalam bentuk dan format yang disesuaikan. Pertimbangan lain untuk menerapkan pendekatan ini, menurut mereka, adalah penentuan tujuan pembelajaran dan pemilihan media atau alat peraga yang akan digunakan. Selanjutnya saran dan kritik mereka terhadap pendekatan ini adalah agar metode Probex dapat diinformasikan dan diterapkan tidak hanya dalam pembelelajaran IPA, tetapi juga mata pelajaran lain dengan pengembangan pembelajaran lebih lanjut.

Tujuan serangkaian prroses pembelajaran yang telah dilakukan adalah agar siswa memiliki bekal pemahaman konsep IPA yang benar, yang selanjutnya dapat mereka aplikasikan dalam kehidupan seharihari. Indikator keberhasilan pelaksanaan pembelajaran dengan metode Probex ini tentunya tidak dapat diamati secara langsung pada saat pembelajaran. Tetapi, dengan sering mengaitkan pengetahuan awal siswa dengan konsep yang baru, mengajak siswa untuk memprediksi dan mengemukakan hipotesis, serta melakukan eksperimen untuk pembuktian penafsiran disetiap pembelajaran IPA, maka nilai-nilai dan sikap ilmiah dapat ditumbuhkan pada diri siswa, sehingga tujuan metode Probex dapat tercapai.

\section{KESIMPULAN}

Berdasarkan hasil penelitian tindakan kelas pada pembelajaran IPA dengan metode Probex (Predict-Observe-Explain) yang sudah peneliti laksanakan pada siswa kelas VII B SMP Negeri 1 Pringapus kabupaten Semarang semester 2 tahun pembelajaran 2013/2014, maka dapat disimpulkan beberapa hal sebagai berikut.

1. Metode Probex dapat meningkatkan pemahaman siswa konsep perubahan zat sebesar $12 \%$.

2. Metode Probex dapat meningkatkan sikap ilmiah sebesar 3\%, kete roses siswa 5\%, keaktifan mengerjakan LKS $15 \%$, Jadi aktivitas siswa ada kenaikan sebe

\section{DAFTAR PUSTAKA}

Arikunto, S. 1990. Prosedur Penelitian Suatu Pendekatan Praktek. Jakarta: Rhineka Cipta.

Depdikbud. 1996. Penelitian Tindakan Kelas. Jakarta: Dirjen Pendidikan Dasar dan Menengah. Haryanto. 2000. Buletin MGMP Jawa Tengah Edisi II. Surakarta.

Kasbolah, K E.S. 1999. Peneltiian Tindakan Kelas. Malang: Universitas Malang.

Rustanto, T. 2001. Pembelajaran Konstruktivisme. Surakarta.

TIM IPA Terpadu 1. 2007. IPA Terpadu SMP/MTs Kelas VII. Jakarta: Yudhistira. 